\title{
Is there Americanization in Catalan election campaigns? A decade of electoral communication strategies from post-modernist perspective
}

\begin{abstract}
We examine how Catalan election campaigns have evolved to post-modernization, a concept coined by Pippa Norris to refer to the current political scenario and how this is reflected in different electoral phases. We analysed four electoral campaigns covering a decade (2003-2012) through 27 face-to-face in-depth interviews conducted with campaign managers for nine political parties. The results indicate that, although Catalan politics is progressing towards the post-modern phase, there are still aspects that are far from fully adapted to the changes affecting all levels of society. Catalan political parties seem to be more comfortable with modern or classical political approaches — such as control over traditional media — and are but slowly reacting to other issues such as citizen demands for more access to, and prominence in, politics.
\end{abstract}

\section{Keywords}

Post-modernization; Permanent campaign; Campaign managers; Political communication; Catalonia.

\section{Authors}

Dr. Carles Pont-Sorribes. Universitat Pompeu Fabra

Dr. Sergi Cortiñas Rovira. Universitat Pompeu Fabra

Dr. Marcel Mauri. Universitat Pompeu Fabra

Dr. Felipe Alonso Marcos. Universitat Pompeu Fabra 


\section{Introduction}

This study examines the persuasion strategies used by the political parties that participated in four regional elections to the Parliament of Catalonia between 2003 and 2012; namely, the 2003 elections, the early 2006 elections, the 2010 elections and the early 2012 elections. The Catalan Parliament, located in Barcelona and representing the people of Catalonia, is the linchpin of the institutional self-government system for this region, which, in turn, forms part of the Spanish state. Elections to the Catalan Parliament indirectly lead to the appointment of the President of the Generalitat — that is, the autonomous (regional) government body — elected by a qualified majority from among the political parties that obtain representation in the legislative chamber. Elections to the Catalan Parliament are considered key elections in Spain — second only to national elections - for two main reasons. First, Catalonia is socially and economically one of the most dynamic regions in Spain and, second, these elections serve as a thermometer of greater selfgovernment demands by Catalan political parties.

This research analyses to what degree Catalan election campaigns have evolved to the post-modern stage. The British political scientist Pippa Norris (2004) coined this term in her premodern/modern/post-modern typology of how electoral campaigns evolve.

"post-modern campaigns are understood as those where the coterie of professional consultants on advertising, public opinion, marketing, and strategic news management become more co-equal actors with politicians, assuming a more influential role within government in a 'permanent' campaign, as well as coordinating local activity more tightly at the grassroots. The news media fragments into a more complex and incoherent environment of multiple channels, outlets, and levels. And the electorate becomes more dealigned in their voting choices. For some citizens, the election may represent a return to some of the forms of engagement found in the pre-modern stage, as the new channels of 
communication potentially allow greater interactivity between voters and politicians."

(Norris, 2004:3)

We started from two hypotheses. The first is that contemporary Catalan politics is shifting towards a post-modern phase, given that social, technological and communication changes have established a new socio-political ecosystem for the twenty-first century that has transformed how politics is understood and done in Catalonia (and in other post-industrial societies). Second, the political parties most critical of the new forms of communication are those which have most fervently adopted new political marketing formulas, persuasion strategies and campaigning techniques $-\mathrm{a}$ priori more representative of more innovative parties.

To implement the research, we analysed four electoral campaigns covering a decade (2003-2012) on the basis of data collected from 27 face-to-face in-depth structured interviews with campaign managers for nine political parties. Participants responded to questions regarding, among other issues, their party's political strategy, their candidate's relationship with the media, the Internet resources used, the use of election polls and surveys, the use of experts, the organization of events and the image of the leader.

\section{Theoretical framework}

The evolution of electoral campaigns has been studied by authors as varied as Maarek (2009), Blumler and Kavanagh (1999), Nimmo (1996) and Norris (2004), to just mention some studies. Evolution in recent times coincides with the phenomenon of 'Americanization' described by Swanson and Mancini (1996). More specifically, these authors referred to a 'scientificization' of electoral campaigns, that is, the growing use of professionals in various arenas, including public opinion research and publicity (De la Torre and Conaghan, 2009; Negrine and Lilleker, 2002; Mancini, 1999). This 'scientificization', considered a main feature of the Americanization of politics, coincides in time with other transformations, including growing public disaffection with politics. 
Norris has, however, criticized the concept of Americanization, arguing that "yet instead of a specifically 'American' development, or alternatively the growth of 'political marketing', as Scammell and others suggest, the interpretation [...] seeks to understand changes in election campaigning as part of the modernization process rooted in technological and political developments common in many post-industrial societies" (2004:3). She understands the transformation of contemporary politics to be much broader and deeper in that it reflects technological and cultural changes that outweigh any possible American cultural or economic influence (Negrine and Papathanassopoulos, 1996). Other authors, also adopting a stance closer to the position maintained by Norris (2000, 2004), refer to 'hybridization' between Americanization trends, technological advances and a return to pre-modern principles (Norris, 2004) — reflected in greater public participation, more direct contact with voters and a feeling of proximity with the political leadership (Nord, 2006). Negrine, Mancini, Holtz-Bacha and Papathanassopoulos (2007), who published an exhaustive study regarding the professionalization of communication, define this concept as:

“...a process of adaptation to, and as such a necessary consequence of, changes in the political system on the one side and the media system on the other and in the relationship of the two systems. These changes follow from the modernization of society, which is a development that is still going on and will take place in similar political systems sooner or later. Professionalization in this sense is a general and not culture-bound concept. Its actual appearance and the degree of professionalization in a given country are however dependent on a country's specific social and political structures and processes.” (Negrine, Mancini, Holtz-Bacha and Papathanassopoulos, 2007:10)

These authors consider the Americanization and scientificization of electoral campaigns, communication professionalization and the modernization of politics in broadranging terms, rating them as controversial issues in modern political communication. Other authors defend professionalization and even reclaim an area of study for political public relations (Strömbäck and Kiousis, 2011). 
Using a similar methodology to ours, based on in-depth interviews, Serazio (2014) described the impact of changes in the media on political communication managers and vice versa, concluding that these changes may pose a threat to certain ideals corresponding to the public sphere. The same author also claimed that electoral professionalization and campaign fragmentation overwhelms traditional journalists with vast quantities of news.

Classifications are undoubtedly useful both in terms of analysing and understanding how political communications — and, most particularly, electoral campaign communications — are changing and in providing insights to the evolution of political persuasion strategies. Here we focus, as better suited to our object of study, on Pippa Norris' (2004) typology, which classifies electoral campaigning in terms of strategies reflecting three distinct historical periods: pre-modern (midnineteenth century to the 1950s), modern (1960s to 1980s) and post-modern (since the 1990s).

For Norris (2004), pre-modern electoral campaigns (mid-nineteenth century to the 1950s) are contextualized by interpersonal and non-professional communications between candidates and voters. Such campaigns are based on local and decentralized organization by volunteers and the use of a partisan press, posters and pamphlets. Coordination is by party leaders and preparations are short-term and ad hoc. Campaign events are typically localized public rallies, doorstep canvassing and visits to local communities. Budgets are small and the electorate is strongly partisan. In premodern campaigns local party organizers select candidates, implement resource planning and develop the infrastructure linking voters with candidates. Almost all activity is generated and concentrated in local communities. As she has written,

“pre-modern campaigns are understood to display three characteristics: the campaign organization is based upon direct forms of interpersonal communications between candidates and citizens at local level, with short-term, ad-hoc planning by the party leadership. In the news media, the partisan press acts as core intermediary between parties and the public. And the electorate is anchored by strong party loyalties. Typically in these campaigns local parties selected the candidates, rang the doorbells, 
posted the pamphlets, targeted the wards, planned the resources, and generally provided all the machinery linking voters and candidates. For citizens the model is one that is essentially local-active, meaning that most campaigning is concentrated within local communities, conducted through more demanding political activities like rallies, doorstep canvassing, and party meetings.” (Norris, 2004: 3)

The second Norris (2004) model is the modern electoral campaign (1960s to 1980s), coordinated nationally through a more professional machinery. The approach is much more party-focused, with campaigning coordinated from central party headquarters and relying on specialist communication advisors. Public opinion polls and surveys are used to a limited degree during the campaign. In the mass media sphere, politicians and their advisors organize polls, design publicity and prepare their topics of the day for the media. National television, as the main forum for events, projects politics as just another show of the society of spectacle as described by Debord (1977). News broadcasts and live prime-time appearances on television become a battleground for capturing electorate attention. Campaign events not only focus on rallies, but on news management, press conferences and photo-ops. Budgets are moderate, but logically are set higher than for pre-modern campaigns. Norris describe the modern electoral campaign as those,

"with a party organization coordinated more closely at central level by political leaders, advised by external professional consultants like opinion pollsters. In the news media, national television becomes the principal forum of campaign events, supplementing other media. And the electorate becomes increasingly decoupled from party and group loyalties. Politicians and professional advisors conduct polls, design advertisements, schedule the theme de jour, leadership tours, news conferences and photo opportunities, handle the press, and battle to dominate the nightly television news. For citizens, the typical experience of the election becomes more passive, in the sense that the main focus of the campaign is located within national television studios, so that most voters become more distant and disengaged spectators in the process.” (Norris, 2004:3). 
Finally, the third strategy in Norris' typology is the post-modern campaign, which begun to appear from the 1990s in post-industrial societies. It is mainly characterized by professionalization as reflected in the emergence of publicity, public opinion, marketing and strategic communications experts playing key campaign orchestration roles. Their more influential role has led to the development of the concept of the 'permanent campaign' ${ }^{1}$ that, although nationally coordinated, is also tightly controlled at the grassroots level. A more fragmented media environment is composed of multiple broadcasting channels and print media outlets, email, websites and forums. The new possibilities for two-way interaction between citizen-voters and candidate-politicians reflect a return to the proximity of the pre-modern campaign (Norris, 2004). Post-modern campaigns are logically costlier due to the use of professional advisors. Campaigns are also much more intense, rely far less on volunteers and use a wide range of media to deliver persuasive messages.

Blumler and Kavanagh (1999) refer to this post-modern stage as the "third age of political communication”, characterized by the abundance and proliferation of media used in campaigns. The emergence of the Internet is one of the main reasons for the information overload that is leading to a reconfiguration of the concept of political communication. This is because:

1. Politicians need the help of professionals to ensure and manage media coverage.

2. The proliferation of communication channels has led to an increase in the number of new formats.

3. The resurgence of populism in the media and, therefore, in politics, has led to an excessive interest in the private lives and feelings of politicians.

Social scientists generally agree that television — the backbone of all post-modern campaigns — has provoked a crisis in traditional communications between politicians and citizens. Television is largely responsible for what is referred to as 'infotainment' in politics and in election campaigns. The major changes of today reflect the new logic of the media, with referential frames that are increasingly distant from informational objectivity and the unmediated interview format. These 
changes are the outcome of journalistic reorientation towards infotainment, where impact is achieved at the cost of depth. Yet political parties attach great importance to the media attention conferred by television and adapt their discourse and language accordingly, most especially during election campaigns. This adaptation is aided by media professionals hired as part of the party machinery. The logic of television and media discourses mixed with journalistic routines also set the stage for the current hegemony of 'media-events' or 'pseudo-events' (Boorstin, 1961). Such events are not spontaneous, are set up primarily for the purpose of being immediately reported or reproduced, are ambiguously related with the underlying reality of the situation, are intended to be self-fulfilling prophecies and have the ability to reproduce more of the same (Boorstin 1961:11-12). As Tandoc and Skoric point out, "three methods of gathering information are associated with pseudo-events: the interview, the press release and the press conference” (2010:35) corresponding, essentially, to political communication. As other authors have added, staged and mediated events are "incidents either produced only for the purpose of receiving news coverage or adapted to suit the needs of the media” (Kepplinger and Habermier, 1995). Cassady (1998) described pseudo-events as events which "are commonly staged by public relations people attempting to draw news media coverage of activities that otherwise would go unnoticed”. Like all pre-modern tactical moves managed by politicians, the pseudo-event is yet another mechanism featured in post-modern campaigns.

Political communication around post-modern campaigns is based on producing that kind of constructed reality using journalistic routines and media methodologies. Political communication is merely creating capsules of information for consumption that are not based on facts but on illusions. As suggested by other sociological post-modern analysts such as Baudrillard (1994) or Zizek (2002), the era of simulacra and the "desert of the real” is also reflected in politics: hiding the fact that there is nothing that merits hiding. The media play — and run — the simulation game, and post-modern politics has to adapt to daily media routines so as to maintain its socially privileged position. 
These features all together reflect what Pippa Norris (2004) referred to in regard to post-modern campaigning. Below we analyse whether those features of the evolution to post-modernity can be detected in Catalan politics and Catalan Parliamentary elections between 2003 and 2012.

\section{Methodology}

Our main objective was to address the research question regarding whether contemporary Catalan politics is evolving towards post-modernized electoral campaigning as defined by Pippa Norris (2004). In the post-modern stage, social, technological and communication changes in electoral campaigning have established a new socio-political ecosystem that has transformed the way of understanding and doing politics in the twenty-first century. The alternative hypothesis would be that Catalan politics remains trapped at the earlier modern stage (Norris, 2004), more characteristic of the 1960s to the 1980s. To address the research question, the methodology was organized in terms of three phases (A to C).

A. Hermeneutical analysis. A hermeneutical analysis of key texts by Norris $(2000,2004)$ enabled us to identify the main characteristics of contemporary politics and post-modern campaigning in a two-level analysis that assessed possible evolution towards (1) theoretical internalization and (2) practical application of post-modernist concepts. The analysis was based on the creation of ten indicators grouped into four blocks describing theoretical assumptions regarding post-modern campaigning, measured by mean scores for the individual indicators making up each block. Through an analysis of the dedication and interest of campaign managers in complying with these indicators, we could assess whether Catalan election campaigns were progressing towards postmodernization. This dual evaluation of individual indicators making up core assumptions enabled us to assess not only a possible post-modern shift in Catalan politics, but also the degree of conscious internalization of the concept of post-modernization and recognition of a transformation in the rules of the political game. 
Below we define the meaning and scope of the four blocks and ten indicators that would point to an evolution of Catalan electoral campaigns towards post-modernism.

Block 1 Assumption. Intensification of the permanent campaign.

This assumption arises from the idea that there is no sharp division between campaign and noncampaign periods. Rather, campaigning is ongoing, although more intense as elections approach and the electoral machinery is mobilized. The fact that major changes are made in routines, teams or machinery in the pre-election period, however, is more than a mere intensification of the permanent campaign: it is, in fact, the stuff of post-modern campaigns (Norris, 2004). This assumption translates into two indicators: Maintaining production routines (Indicator 1) and Maintaining the machinery (Indicator 2).

Block 2 Assumption. Loss of control over communications.

This assumption derives from the idea that the emergence of new communication channels has led to a fragmentation of the communicative ecosystem, with anyone now able to produce content from any of a multitude of platforms. Communication is no longer vertical and asymmetrical or produced exclusively by the powers that be. Fragmentation leads to a loss of hegemonic power over communications and, consequently, inspires tactical efforts to both regain control and engage in new communication channels and take advantage of the strategic opportunities offered. This assumption is reflected in two indicators: Managing traditional media visibility, image and discourse (Indicator 3) and Participation in Web 2.0. communication (Indicator 4).

Block 3 Assumption. Loss of hierarchical power

This assumption arises from the notion that power in modern campaigns is reflected in content production and the ability to set the agenda, which essentially depict the degree of monopolization of politics. In the post-modern era, such monopolies no longer hold. As mentioned earlier, 
communicational fragmentation is allowing voters to set part of the agenda. Moreover, the business idea that the voter is an important and influential 'customer' has also taken root. Political power cannot ignore these developments, so politicians try to mobilize the public in a dual tactical move: making it clear that existing protagonism by citizens is not denied and granting even more protagonism to citizens. This strategy is realized as an apparent partial withdrawal from centre stage with a dual aim: projection as a social provider and not just as the main leading actor, and at the same time, acquisition of as much feedback as possible. These ideas are reflected in three indicators: Continuous reception monitoring (Indicator 5), Demand for citizen participation (Indicator 6) and Tactical return to pre-modern proximity techniques (Indicator 7).

Block 4 Assumption. The need for experts

This assumption draws on the idea that politics cannot be left behind by the growing professionalization and scientific and technological advances affecting other sectors of society. Post-modern political parties need to draw on all possible resources to ensure success and this requires a more professional approach and the use of experts in communication, applied marketing and other fields. Reflecting this assumption are three indicators: Use of communication experts (Indicator 8), Outsourcing of services (Indicator 9) and Exploitation of marketing techniques (Indicator 10).

B. In-Depth Interviews. To assess the possible evolution of Catalan politics toward postmodernity, face-to-face in-depth interviews were conducted with campaign managers for nine political parties participating in elections to the Catalan Parliament between 2003 and 2012. This period included the regional 2003 elections, the early 2006 elections, the 2010 elections and the early 2012 elections. The interviews were conducted in the weeks subsequent to the elections. In in-depth interview approach has been successfully used by other authors, e.g., Serazio (2014), to collect empirical evidence of the experiences of campaign managers and spin doctors. We believe that this ethnographic aspect of our methodology contributes insights that would not be possible 
from an analysis of content that possibly could not be verified directly. The research got $100 \%$ response rate, as all campaign managers from all parties agreed to be interviewed.

The research thus covered four election campaigns in a period spanning a decade. In the 27 interviews, lasting an average of 90 minutes each, respondents answered questions about various aspects of their political campaigns that were designed to uncover information relevant to each of the indicators in our political post-modernization scale. Table 1 summarizes details of political parties and interviewed campaign leaders by election year. The grey boxes indicate that a particular political party did not exist at the time of the election in question.

TABLE 1. Face-to-face in-depth interviews with 27 campaign managers by political party and election year.

\begin{tabular}{|c|c|c|c|c|}
\hline Political party & 2003 elections & 2006 elections & 2010 elections & 2012 elections \\
\hline $\begin{array}{l}\text { Convergència } \text { I Unió } \\
\text { (CIU) }\end{array}$ & David Madí & David Madí & David Madí & Lluís M. Corominas \\
\hline $\begin{array}{l}\text { Partit Socialista de } \\
\text { Catalunya (PSC) }\end{array}$ & Miquel Iceta & José Zaragoza & Jaume Collboni & Daniel Fernández \\
\hline Partit Popular (PP) & $\begin{array}{l}\text { Francesc } \\
\text { Vendrell }\end{array}$ & $\begin{array}{l}\text { Francesc } \\
\text { Vendrell }\end{array}$ & Jordi Cornet & Dolors Montserrat \\
\hline $\begin{array}{l}\text { Esquerra Republicana de } \\
\text { Catalunya (ERC) }\end{array}$ & Ernest Benach & Xavier Vendrell & Xavier Vendrell & Lluís Salvadó \\
\hline $\begin{array}{l}\text { Iniciativa - Els Verds } \\
\text { (ICV) }\end{array}$ & Jordi Guillot & Jordi Guillot & Marc Rius & Marc Rius \\
\hline $\begin{array}{l}\text { Ciutadans (C's) } \\
\text { Solidaritat Catalana per } \\
\text { la Independència (SI) }\end{array}$ & & Antonio Robles & $\begin{array}{l}\text { José M. Villegas } \\
\text { Emili Valdero }\end{array}$ & $\begin{array}{l}\text { José M. Villegas } \\
\text { Jordi Anguera }\end{array}$ \\
\hline $\begin{array}{l}\text { Reagrupament } \\
\text { Independentista (RI) }\end{array}$ & & & Xavier Borràs & \\
\hline $\begin{array}{ll}\text { Candidatura } & \text { d'Unitat } \\
\text { Popular (CUP) } & \\
\end{array}$ & & & & Marc Sallas* \\
\hline
\end{tabular}

Table 1. Grey boxes indicate non-participation due to the non-existence of the party in a particular election year. *CUP did not have a campaign leader as such, so Marc Sallas, a member of the party secretariat, was interviewed instead.

C. Content analysis. The content of each in-depth interview was analysed in terms of Indicators 1

to 10 , each assigned a value between 1 and 3, where 3 reflected the highest level of evolution 
towards post-modernity in the party's policymaking for the various electoral campaigns included in the analysis.

The encoding process was carried out in two phases. A pre-test was first conducted in which the four authors evaluated each of the indicators for the first electoral campaign (2003) to compare results and validate the tool. Coincidence initially ranged between $80 \%$ and $100 \%$. Indicators where coincidence was under 90\% were reformulated (they had originally been conceived as coded in reverse). Re-testing increased coincidence to $95 \%$.

The ten indicators grouped into four assumptions regarding political post-modernity in Catalan election campaigns were scored between 1 and 3 depending on the importance attached to each issue by the respondent and interviewer perceptions of the efforts invested in them. Thus, in terms of political campaign planning and perceptions, 1 indicated that little or no importance was attached to the assessed issues, 2 indicated that the assessed issues were taken into account to some small degree but not as core elements; and finally, 3 indicated that the assessed issues were regarded as central. Higher scores for the indicators reflected higher levels of evolution towards post-modernity as defined by Pippa Norris and, likewise, higher scores for each block of assumptions indicated the degree to which political leaders had internalized certain basic features of post-modern campaigning.

Once the indicators were coded and scored we conducted analyses as follows: (1) the degree of evolution of Catalan politics towards post-modernity; (2) insights revealed by indicator scores, for instance, best and worst scores; (3) insights regarding how politicians view their role in society; and (4) differences, if any, between political parties. The results of these analyses are described in turn below.

\section{Results}


Strategic shifts towards post-modernity are evidence of a transformation in the way of doing politics by Catalan political parties and their campaign managers, yet differences are evident between indicators, blocks and parties.

As can be seen in Table 2, the indicators whose scores most increased over the four elections covered by this analysis were Indicator 2 (Maintenance of the machinery) and Indicator 8 (Use of communication experts). Indicator 2 scores are evidence of the disappearance of the distinction between campaign and pre-campaign periods, resulting in the permanent campaign referred to by Norris. Transition to, and consolidation of, the permanent campaign as a single phase marked only by differences in intensity is thus evident. As for Indicator 8, technological advances in communications have made policy tools available that the different political parties have taken advantage of using communication experts such as sociologists, statisticians, publicists, managers and community managers, all of whom are coming to play an increasingly important role in Catalan politics. It is now already common to create and use teams contributing non-political knowledge to the implementation of different political activities.

TABLE 2. Post-modernization indicator scores for Catalan election campaigns (2003-2012).

\begin{tabular}{cccccc} 
Indicator & $\mathbf{2 0 0 3}$ & $\mathbf{2 0 0 6}$ & $\mathbf{2 0 1 0}$ & $\mathbf{2 0 1 2}$ & Increase* \\
\hline $\mathbf{1}$ & 2.0 & 2.0 & 2.8 & 2.9 & $\mathbf{( + 0 . 9 )}$ \\
$\mathbf{2}$ & 2.0 & 2.0 & 2.8 & 2.9 & $\mathbf{( + 0 . 9 )}$ \\
$\mathbf{3}$ & 3.0 & 2.8 & 2.9 & 3.0 & $(+0.0)$ \\
$\mathbf{4}$ & 2.2 & 1.7 & 2.8 & 2.9 & $(+0.7)$ \\
$\mathbf{5}$ & 2.2 & 2.5 & 2.6 & 2.3 & $(+0.1)$ \\
$\mathbf{6}$ & 1.0 & 1.3 & 1.8 & 1.9 & $\mathbf{( + 0 . 9 )}$ \\
$\mathbf{7}$ & 2.0 & 2.3 & 2.0 & 2.5 & $\mathbf{( + 0 . 5 )}$ \\
$\mathbf{8}$ & 1.8 & 2.2 & 2.4 & 2.9 & $\mathbf{( + 1 . 1 )}$ \\
$\mathbf{9}$ & 2.4 & 2.5 & 2.3 & 2.4 & $\mathbf{( + 0 . 0 )}$ \\
$\mathbf{1 0}$ & 2.4 & 3.0 & 2.8 & 2.9 & $\mathbf{( + 0 . 3 )}$ \\
\hline
\end{tabular}

Table 2. Score scale of 1 to 3 . Bold highlights the greatest increases. *Increases were calculated as the difference between 2012 and 2003 scores.

Of the indicators whose scores increased least, we can observe two patterns. First, some scores were already high from the outset and so left little room for improvement, as was the case of 
Indicator 3 (Managing traditional media; +0.0). Traditional media are a central communication axis in modern political campaigns and even have a role to play in post-modern campaigns in candidates' agendas, given their broad coverage and great capacity to influence. Second, some scores remained consistently low over all four elections, as was the case with Indicator 5 (Continuous reception monitoring), where the increase was minimal $(+0.1)$. While Catalan political parties are increasingly working with multidisciplinary teams of experts who analyse voter reception of policies, communication is still asymmetric; that is, the focus is on public response to unilateral decisions and on using information to benefit the party, rather than on empowering the electorate in terms of decisions regarding the political agenda.

It is interesting to observe the growth in Indicator 4 (Participation in Web 2.0 communications), which reflects use of an alternative channel of mass communication that is gradually coming to play a central role in ensuring the visibility and reach of political parties. Web 2.0 communication, as an alternative to traditional linear and passive communications, is a reality that is assumed by all the parties. The impact of this form of communication is that it allows voters to share the political stage that was formerly dominated by politicians. However, it tends to be used by the political parties as yet a new way to ensure visibility and reach, with its potential as a two-way communication tool largely ignored. In other words, the possibilities for constructing a political ecosystem in which the electorate would play a greater role tend to be rejected by Catalan political parties and managers.

Indicator 6 (Demand for citizen participation) showed an overall increase $(+1.0)$, although the starting point was a modest score of 1.0. However, this improvement may not be enough to overcome voter disenchantment based on perceptions of an immobile, unresponsive political class and of limited possibilities of access to politics and of modifying how it functions. This merely underlines the point made above regarding non-exploitation of the possibilities offered by the new media. 
Particularly insightful are signs of public affection/disaffection and politician proximity/remoteness regarding electorates. Such insights were highlighted as a result of the grouping of individual blocks of political assumptions, further broken down into individual indicators that could then be analysed as reflecting intentions, deduced, in turn, from information provided through interviews with campaign managers.

TABLE 3. Mean assumption block scores for Catalan elections (2003-2012).

\begin{tabular}{lcccccc}
\hline & $\mathbf{2 0 0 3}$ & $\mathbf{2 0 0 6}$ & $\mathbf{2 0 1 0}$ & $\mathbf{2 0 1 2}$ & Mean & Increase* \\
\hline BLOCK 1 & 2.0 & 2.0 & 2.8 & 2.9 & 2.4 & $(+0.9)$ \\
BLOCK 2 & 2.6 & 2.3. & 2.9 & 3.0 & 2.7 & $(+0.4)$ \\
BLOCK 3 & 1.7 & 2.0 & 2.1 & 2.2 & 2.0 & $(+0.5)$ \\
BLOCK 4 & 2.2 & 2.5 & 2.1 & 2.4 & 2.3 & $(+0.2)$ \\
\hline
\end{tabular}

Table 3. Maximum score $=3$. *Increases were calculated as the difference between 2012 and 2003 scores.

Block 3, referring to the assumption of a loss of hierarchical power, received the lowest postmodernization scores for Catalan politics. This block includes Indicators 5, 6 and 7 (Continuous reception monitoring, Demand for citizen participation and Tactical return to pre-modern proximity techniques, respectively), whose results over the years show increases of 0.1, 0.9 and 0.5 , respectively, with scores for the last elections of 2.3, 1.9 and 2.5, respectively. Referring to the block overall, the average score of 2 for the 2012 elections and the increase of a mere 0.5 is not commensurate with a post-modern scenario as theorized by Norris. In considering overall block results, lower scoring indicators drag down mean scores. The interest and efforts of the interviewed campaign managers, as represented by the indicators, is a translation into actions of internalized theoretical assumptions regarding the place occupied by politics in society and how the political scenario is expected to develop. While it seems that the political class, as demonstrated by its actions and planning, has internalized the fact that communications have broken down (Block 2, average score 2.7) and that campaigning is ongoing (Block 1, an increase of nearly 1 from 2003 to 
2011), it would seem, in light of our results, that the political class is reluctant to acknowledge certain structural changes in society and to modify its behaviour accordingly.

Finally, we assessed whether the indicator scores provided important information regarding differences between political parties in terms of score increases. Following on what was previously stated, the more established political parties may be more resistant to change, whether in doing politics or in understanding politics and its relationship with society.

TABLE 4. Post-modernization scores for political parties participating in Catalan elections (2003-2012).

\begin{tabular}{cccccc}
\hline Party & $\mathbf{2 0 0 3}$ & $\mathbf{2 0 0 6}$ & $\mathbf{2 0 1 0}$ & $\mathbf{2 0 1 2}$ & Increase* $^{*}$ \\
\hline PP & 21 & 24 & 26 & 27 & $(+5)$ \\
PSC & 19 & 20 & 24 & 26 & $\mathbf{( + 7 )}$ \\
CIU & $\mathbf{2 3}$ & 22 & 26 & 26 & $(+3)$ \\
ERC & 21 & 20 & 23 & 26 & $(+5)$ \\
ICV & 21 & 22 & 26 & 27 & $\mathbf{( + 6 )}$ \\
C’s & & $\mathbf{2 6}$ & 26 & $\mathbf{2 9}$ & $(+2)$ \\
SI & & & $\mathbf{2 8}$ & 26 & $(-2)$ \\
RI & & & 20 & & $(=)$ \\
CUP & & & & 24 & $(=)$ \\
& & & & &
\end{tabular}

Table 4. Maximum score $=30 . *$ Increases were calculated as the difference between 2012 and 2003 scores.

As can be seen in Table 4, there was clear evidence of a shift towards post-modernity by all the major political parties, although the evolution was slower in parties that had previously held power. The new parties that came on the scene from 2006, nonetheless, seem to much better reflect the contemporary Catalan political transition towards post-modernity; since they have already adopted a strong post-modern tradition, they need make hardly any major adjustments to their policymaking. The traditional political parties that view themselves as established institutions, that take themselves too seriously and whose communications are based on a determinedly unilateral programme and agenda, are not as yet fully participating in the new post-modern politics. 
C's in 2006 and 2010 and SI in 2010 were the top-scoring parties in their earliest participations in Catalan elections. The only case of a negative trend was SI (-2), possibly attributable to the party's association with a highly visible, but also polemical, Catalan media personality, Joan Laporta, former president of Football Club Barcelona during a particularly successful period (2003-2010). By 2012, the fact that Joan Laporta was no longer the head of what was a rather marginal party most likely contributed to the drop in scores. Nonetheless, more post-modern than Joan Laporta is difficult to imagine, as his entry into politics as an outsider captures the very essence of postmodernity: absolute familiarity and ease in dealing with the media, communicative expertise, premodern proximity to citizens and a certain frivolity (which renders visible the political loss of hierarchical power).

Political parties representing regional sections of national parties, namely, the Catalan PSC and the Catalan PP, show evidence of evolution towards post-modernist campaigns, as does the regional Catalan party ERC (a 5-point increase). A slightly different case is the Catalan CIU, with a smaller increase (3 points) but with high scores from the first election analysed. Indeed, its scores for indicators and blocks, whether relative or absolute, point to it as a pioneer in introducing new ways of doing politics that represent a clear shift towards post-modern politics. However, it seems that other parties have caught up with CIU, which, by now, would seem to have stagnated.

\section{Conclusions}

The overall research results clearly indicate a post-modernization of Catalan electoral campaigns, but not necessarily an Americanization of Catalan politics. We prefer to use Norris' concept, because, as Norris explains, and our results can confirm, the evolution towards a new ways of policy-making is not an exclusive phenomenon of United States.

The scores for each of the indicators and for each assumption block - designed to measure evolution towards post-modernity — increased over the four elections included in the study between 2003 and 2012. The consolidation of post-modernist in contemporary Catalan politics is 
also evident in nearly all of the nine political parties studied. Finally, the left or right wing ideologies of the parties had no bearing on the level of post-modernization of the corresponding electoral campaigns.

Technological advances as applied or applicable to communications has made policy tools available that the different political parties have not failed to take advantage of. Communication experts (such as sociologists, statisticians, publicists, managers and community managers) are coming to play an increasingly important role in Catalan politics, where the use of teams of experts who contribute non-political knowledge to the implementation of political strategies is now common.

If, rather than focus on indicators in isolation, we view different electoral campaigns as a whole, we also find progressively improved scores that mark a transition from modern to post-modern campaigning strategies. The 2003 and 2006 campaigns scored an average of 2.1 and 2.2, respectively, for all ten indicators, whereas the scores for the 2010 and 2012 campaigns continued the upward trend, with scores of 1.5 and 2.6 , respectively. While there seems to be a definite and accelerating trend toward post-modernization, the data need to be interpreted with care until the research can be extended to include future Catalan elections.

Although the data point to a steady increase overall in post-modernization scores for both individual indicators and electoral campaigns, there continue to be deficient areas. The mean overall of the electoral campaigns score ( +0.5 increase) over a decade is slight and timid and can be attributed to low scores for certain indicators of post-modernization in Catalan contemporary politics. Catalan electoral campaigns, therefore, despite making notable advances towards Norris' post-modern phase, still need to adapt further to changes taking place at all levels of society. Catalan political parties seem to be more comfortable with modern or classical approaches — such as control over traditional media — and are but slowly reacting to other requirements, such as responding to an electorate that demands more access and prominence in politics. 


\section{Declaration of Conflicting Interests}

The authors declared no potential conflicts of interest with respect to the research, authorship, and/or publication of this article.

\section{Funding}

The authors disclose receipt of the following financial support for the research, authorship, and/or publication of this article: Parliament of Catalonia, Generalitat de Catalunya, Government Department of Catalonia and the Provincial Council of Barcelona.

\section{Notes}

1. The concept of 'permanent campaign' was defined in the early 1980s in a book titled The Permanent Campaign by Sidney Blumenthal, a US journalist and presidential advisor to Bill Clinton, although the concept is originally attributed to Patrick Caddell, a pollster for President Jimmy, who wrote a 1976 memo titled "Initial Working Paper on Political Strategy that explained that governing requires a "continuing political campaign”. Other sources claim that Blumenthal was inspired by Leon Trotsky's notion of a 'permanent revolution' in that the permanent campaign (or revolution) is a process of transformation that continues even after power is obtained. The permanent campaign refers to the fact that politicians, using experts, monitor media exposure and approval ratings almost continuously from the day after election until the next election.

\section{References}

Baudrillard, J. (1994). Simulacra and Simulation. Michigan: University of Michigan Press.

Blumler, J. G. ,\& D. Kavanagh. (1999). The third age of political communication: Influences and features. Political Communication, 16 (3): 209-230.

Boorstin, D. J. (1961). The image: A guide to pseudo-events in America. New York: Harper. 
Capdevila, A., \& C. Pont. (2012). La campanya fragmentada: Comunicació política i comportament electoral a les eleccions catalanes de 2010. Girona: Documenta Universitària.

Cassady, D. (1998). Staged news, History of the mass media in the United States: An encyclopedia (pp. 623-624). Chicago: Routledge.

Cortiñas, S., \& C. Pont. (2009) Premsa diària i comunicació política. La percepció del projecte de reforma de l'Estatut de Catalunya en 12 diaris espanyols. Anàlisi: Quaderns de Comunicació $i$ Cultura, 38: 117-134.

De la Torre, C., \& C. Conaghan. (2009). The Hybrid Campaign Tradition and Modernity in Ecuador’s 2006 Presidential Election. International Journal of Press/Politics, 4 (3): 335-352.

Kepplinger, H. M., \& J. Habermier. (1995). The impact of key events on the presentation of reality. European Journal of Communication, 10 (3): 371-390.

Mancini, P., \& D.L. Swanson. (1996). Politics, Media and Modern Democracy: An Introduction. In D. L. Swanson \& P. Mancini (Eds.), Politics, Media, and Modern Democracy: An International Study of Innovations in Electoral Campaigning and Their Consequences. Westport, CT: Praeger.

Mancini, P. (1999). New Frontiers in Political Professionalism. Political Communication, 16: 23145.

Negrine, R. M.; Mancini, P.; Holtz-Bacha, C., \& S. Papathanassopoulos. (2007). The Professionalization of Political Communication. Chicago: Intellect Books.

Negrine, R. M., \& D.G. Lilleker. (2002). The Professionalization of Political Communication Continuities and Change in Media Practices. European Journal of Communication, 17 (3): 305-323.

Negrine, R. M., \& S. Papathanassopoulos. (1996). The ‘Americanization’ of Political Communication: A Critique. Harvard International Journal of Press/Politics, 1 (2): 45-62.

Nimmo, D. D. (1970). The Political Persuaders. The Techniques of Modern Election Campaign. New Jersey: Prentice-Hall. 
Nimmo, D. D. (1996). Politics, media, and modern democracy: The United States. In D.L. Swanson \& P. Mancini (Eds). Politics, media, and modern democracy: An international study of innovations in electoral campaigning and their consequences. Greenwood Publishing Group.

Nord, L. W. (2006). Still the Middle Way. A Study of Political Communication Practices in Swedish Election Campaigns. International Journal of Press/Politics, 11(1), 64-76.

Norris, P. (2004). The evolution of election campaigns: Eroding political engagement? Cambridge: Harvard University.

Norris, P. (2000). A virtuous circle? Political communications in post-industrial democracies. Cambridge: Cambridge University Press.

Norris, P. (1995). Political communications in British election campaigns: Reconsidering media effects. British Elections and Parties Yearbook, 5 (1): 125-138.

Pallarès, F.; Gifreu, J., \& Capdevila, A. (Eds). (2007). De Pujol a Maragall. Girona: Documenta Universitaria.

Pericot, J., \& Capdevila, A. (Eds). (2009). L'espectre del Tripartit. Girona: Documenta Universitaria.

Pont, C., \& Capdevila, A. (Eds.) 2014. Del carrer a les urnes: El dret a decidir en campanya. Girona: Documenta Universitaria.

Pont-Sorribes, C., \& S. Cortiñas-Rovira. (2011). Journalistic practice in risk and crisis situations: Significant examples from Spain. Journalism, 12 (8): 1052-1066.

Serazio, M. (2014). The New Media Designs of Political Consultants: Campaign Production in a Fragmented Era. Journal of Communication, 64 (4): 743-763.

Strömbäck, J., \& Kiousis, S. (Eds). (2011). Political Public Relations: Principles and Applications. New York: Routledge. 
Tandoc Jr., E. C., \& M. M. Skoric. (2010). The pseudo-events paradox: how pseudo-events flood the Philippine press and why journalists don't recognize it. Asian Journal of Communication 20 (1): $33-50$.

Wolton, D. (1989). Communication politique: Construction d'un modèle. París: CNRS Editions.

Zizek, S. (2002). Welcome to the Desert of the Real. London: Verso. 